\title{
The mechanisms by which polyamines accelerate tumor spread
}

\author{
Kuniyasu Soda
}

\begin{abstract}
Increased polyamine concentrations in the blood and urine of cancer patients reflect the enhanced levels of polyamine synthesis in cancer tissues arising from increased activity of enzymes responsible for polyamine synthesis. In addition to their de novo polyamine synthesis, cells can take up polyamines from extracellular sources, such as cancer tissues, food, and intestinal microbiota. Because polyamines are indispensable for cell growth, increased polyamine availability enhances cell growth. However, the malignant potential of cancer is determined by its capability to invade to surrounding tissues and metastasize to distant organs. The mechanisms by which increased polyamine levels enhance the malignant potential of cancer cells and decrease anti-tumor immunity are reviewed. Cancer cells with a greater capability to synthesize polyamines are associated with increased production of proteinases, such as serine proteinase, matrix metalloproteinases, cathepsins, and plasminogen activator, which can degrade surrounding tissues. Although cancer tissues produce vascular growth factors, their deregulated growth induces hypoxia, which in turn enhances polyamine uptake by cancer cells to further augment cell migration and suppress CD44 expression. Increased polyamine uptake by immune cells also results in reduced cytokine production needed for anti-tumor activities and decreases expression of adhesion molecules involved in anti-tumor immunity, such as CD11a and CD56. Immune cells in an environment with increased polyamine levels lose anti-tumor immune functions, such as lymphokine activated killer activities. Recent investigations revealed that increased polyamine availability enhances the capability of cancer cells to invade and metastasize to new tissues while diminishing immune cells' anti-tumor immune functions.
\end{abstract}

Keywords: Polyamine, metastasis, spermine, spermidine, LAK, LFA-1

\section{Introduction}

Polyamines, which include spermidine and spermine, are polycations with three or four amine groups. Almost all cells can produce polyamines, but their production is especially high in rapidly growing cells. Polyamine concentrations are often increased in the blood and urine of cancer patients, and these increased levels have been shown to correlate with poor prognosis [1]. The increased blood and urinary polyamine levels are attributable to increased polyamine synthesis by cancer cells, since these increases can be abolished by complete eradication of tumors by surgery or radio-chemotherapy [2-5]. The capacity of cancer tissue to produce abundant polyamines likely contributes to cancer cells' enhanced

\footnotetext{
Correspondence: soda@omiya.jichi.ac.jp
}

Department of Surgery and Cardiovascular Research Institute, Saitama Medical Center, Jichi Medical University, 1-847 Amanuma, Omiya, Saitamacity, Saitama (330-0834), Japan growth rates because polyamines are indispensable for cellular growth, which may at least partially explain why cancer patients with increased polyamine levels have a poorer prognosis [4-9]. However, an important factor that determines the malignant potential of cancer cells is the capability of cells to invade to surrounding tissues and to metastasize to distant organs. Therefore, it is important to understand the role of polyamines in cancer invasion and metastasis. In this review, recent experimental results from our and other groups are discussed.

\section{What are polyamines?}

The natural polyamines, spermidine, and spermine, are found in almost every living cell at high micromolar to low millimolar quantities [10]. Polyamines are synthesized from arginine and s-adenosylmethionine with arginase converting arginine to ornithine, and ornithine

\section{Biomed Central}


decarboxylase (ODC) catalyzing ornithine decarboxylation to form putrescine, a polyamine precursor containing two amine groups (Figure 1). Polyamines are involved in diverse functions involved in cell growth and differentiation, such as DNA synthesis and stability, regulation of transcription, ion channel regulation, and protein phosphorylation [11-14].

Intracellular spermine and spermidine are degraded by spermidine/spermine $\mathrm{N}^{1}$-acetyltransferase (SSAT) and $\mathrm{N}^{1}$-acetylpolyamine oxidase (APAO). SSAT, a highly inducible enzyme, catalyzes the transfer of an acetyl group from acetyl-coenzyme A to the aminopropyl moiety of spermine and spermidine. APAO was previously described as polyamine oxidase but it preferentially catalyzes the oxidation of the $N^{1}$-acetylspermine and $N^{1}$ acetylspermidine produced by SSAT activity. This

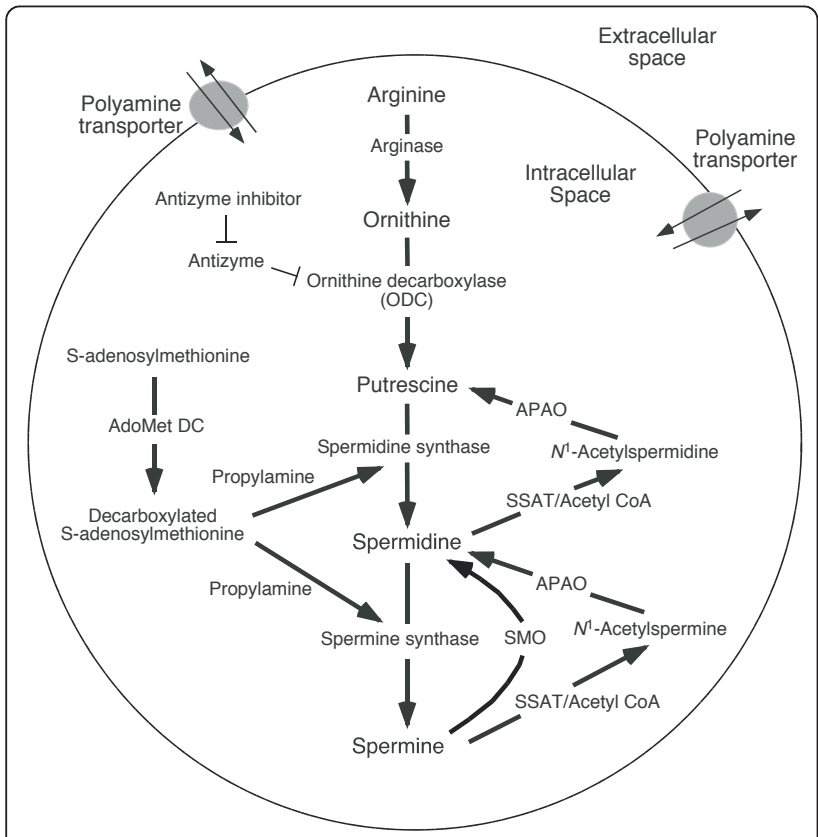

Figure 1 Polyamine biosynthesis, degradation, and transmembrane transport. The polyamines spermine and spermidine are synthesized from arginine. Arginase converts arginine to ornithine, and ornithine decarboxylase (ODC) catalyzes decarboxylation of ornithine to form putrescine, a polyamine precursor containing two amine groups. ODC, a rate-limiting enzyme with a short half-life, is inhibited by antizyme, and antizyme is inhibited by an antizyme inhibitor. S-adenosylmethionine decarboxylase (AdoMetDC) is the second rate-limiting enzyme in polyamine synthesis and is involved in the decarboxylation of Sadenosylmethionine. Spermidine synthetase and spermine synthase are constitutively expressed aminopropyltransferases that catalyze the transfer of the aminopropyl group from decarboxylated Sadenosylmethionine to putrescine and spermidine to form spermidine and spermine, respectively. Polyamine degradation is achieved by spermine/spermidine $N^{1}$-acetyltransferase (SSAT) and $\mathrm{N}^{1}$-acetylpolyamine oxidase (APAO). In addition, spermine oxidase (SMO) specifically oxidizes spermine. Polyamines are transported across the membrane transmembrane by the polyamine transporter. oxidation results in the production of $\mathrm{H}_{2} \mathrm{O}_{2}, 3$-acetoaminopropanal, and putrescine or spermidine (Spd), depending on the initial substrate [15-17]. Mammalian spermine oxidase (SMO) is an inducible enzyme that specifically oxidizes spermine, with the production of $\mathrm{H}_{2} \mathrm{O}_{2}$, 3-aminopropanal (3AP) and spermidine [16,17].

In addition to de novo synthesis and degradation, cellular polyamine concentrations are also regulated by transmembrane transport where cells take up polyamines from their surroundings or export them to the extracellular space (Figure 1).

\section{Polyamines and cancer}

Polyamine biosynthesis is up-regulated in actively growing cells, including cancer cells $[10,18,19]$, therefore polyamine concentration as well as gene expression and activity of enzymes involved in polyamine biosynthesis, especially ODC, are higher in cancer tissues than in normal surrounding tissues [8,20-25].

Numerous reports have shown that both blood and urine polyamine concentrations are often increased in cancer patients $[4,5,7,8,10]$. A close correlation between blood polyamine levels and the amount of urinary polyamines has also been found in cancer patients [1]. Moreover, these levels decrease after tumor eradication and increase after relapse [2-5,23], indicating that polyamines synthesized by cancer tissues are transferred to the blood circulation and kidney, where they are excreted into the urine [26].

Polyamines are also produced in other parts of the body and can be transported to various organs and tissues such as the intestinal lumen where polyamines are absorbed quickly to increase portal vein polyamine concentrations [27]. The majority of spermine and spermidine in the intestinal lumen is absorbed in their original forms because there is no apparent enzymatic activity present to catalyze their degradation [28]. Polyamines absorbed by the intestinal lumen are distributed to almost all organs and tissues in the body [29] as demonstrated by the increased blood polyamine levels in animals and humans produced in response to continuous enhanced polyamine intake for six and two months, respectively [30,31]. However, short-term increased polyamine intake failed to produce such increases [30-32], possibly because of the homeostasis that inhibits acute changes in intracellular polyamine concentration. On the other hand, reductions in blood polyamine concentration were not achieved only by restricting oral polyamine intake. As such, at least two sources of intestinal polyamines are postulated: foods and intestinal microbiota. Decrease in blood polyamine levels can be successfully achieved by eliminating intestinal microbiota in addition to restricting food polyamines [33]. Taken together, these results indicate that polyamines 
are not only produced by cancer tissues but are also supplied from the intestinal lumen and together appear to influence polyamine levels in the body of cancer patients.

\section{Polyamines in the body}

In vitro experiments showed that cultured cells take up polyamines from their surroundings [34,35]. In blood circulation, the majority of polyamines are contained in blood cells, especially in red and white blood cells, and therefore increases in blood polyamine concentration indicate concurrent increases in polyamine levels in blood cells [36]. Similarly, intracellular polyamine concentrations in cells of otherwise normal tissues and organs in cancer patients can be increased [37]. One examination showed that spermidine and spermine levels are increased in the normal colon mucosa of cancer patients compared to the normal colon mucosa from patients without cancer [37], although another study was unable to detect these differences [38]. Given that polyamine concentrations are increased in the blood cells of cancer patients and numerous blood cells with increased polyamine concentrations exist in normal tissues, the polyamine concentration in normal tissues of cancer patients with increased blood polyamine levels might also be increased. In addition, orally administered radiolabeled polyamines have been shown to be immediately distributed to almost all organs and tissues $[29,39,40]$.

Polyamine concentrations in the blood vary considerably among healthy individuals such that concentrations are not necessarily higher in cancer patients than in otherwise normal subjects $[41,42]$ and this wide variation precludes the use of polyamine levels as a tumor marker as well as making detection of differences in polyamine concentrations in normal tissues of cancer patients and normal subjects difficult. The kinesis of polyamines may allow distant tissues and organs to influence polyamine levels of all cells in an organism.

\section{Polyamines and cancer spread}

Patients with increased polyamine levels either in the blood or urine are reported to have more advanced disease and worse prognosis compared to those with low levels, regardless of the type of malignancy [4-9]. Because polyamines are essential for cell growth, the increased capability of polyamine synthesis could reflect enhanced tumor proliferation. Therefore, inhibition of polyamine synthesis and availability by cancer cells could retard cancer cell growth. The efficacy of polyamine depletion is prominent in animal experiments. Inhibition of polyamine synthesis by DL- $\alpha$-difluoromethylornithine (DFMO), an inhibitor of ODC that catalyzes the first rate-limiting step in polyamine biosynthesis, with or without methylglyoxal-bis-guanylhydrazone (MGBG), an inhibitor of S-Adenosylmethionine (SAM) that is required for polyamine synthesis, successfully suppressed tumor growth and prolonged survival of tumor-bearing animals [43-46]. Although the efficacy of polyamine restriction is not as apparent in humans as in animals $[47,48]$, inhibition of polyamine synthesis by DFMO successfully suppressed the progression of neoplastic disease [49-52].

However, a major factor that directly influences the prognosis of patients with malignant disease is the capability of cancer cells to invade surrounding tissues and organs and evade immune cell defenses to metastasize to distant organs. In animal experiments, inhibition of polyamine synthesis by DFMO and/or MGBG not only reduced tumor growth but also decreased the amount of metastasis, resulting in prolonged survival of tumor bearing animals $[43,44,46,53-55]$. Therefore, the effect of polyamines on the metastatic potential of cancer cells, the host's anti-tumor immunity, and the corresponding mechanisms involved should be taken into consideration.

\section{Mechanism of metastasis and involvement of polyamines (Figure 2)}

There are several steps that occur during metastasis: separation of cancer cells from the tumor cluster (5-a); transmigration of cells from the original cluster to the circulation (5-b); and rooting and colonization in new organs and tissues (5-c) [56,57]. In addition, metastasis is completed only when cancer cells can successfully escape from the anti-tumor immune function of the host during this process (5-d). In this section, the mechanism of cancer metastasis and the involvement of polyamines are discussed.

\section{5-a. Separation of cancer cells from the tumor cluster, and the role of polyamines}

Cancer metastasis begins when cancer cells separate from the tumor cluster. This separation is initiated by decreased cell adhesion, which is normally maintained by the presence of adhesion molecules involved in intercellular binding and binding between cells and the extracellular matrix. Hypoxia, a common condition in cancer tissues, exerts a strong pressure on cells to separate from the tumor cluster and migrate into circulation $[58,59]$. Despite their de novo angiogenesis, solid tumors have scattered regions where oxygen delivery is compromised due to diffusion limitations, structural abnormalities of tumor microvessels, and disturbed microcirculation [60]. The cellular response to hypoxia involves the stabilization and resultant increase in levels of hypoxia inducible factor-1 (HIF-1), a transcription factor that enhances gene expression to promote 


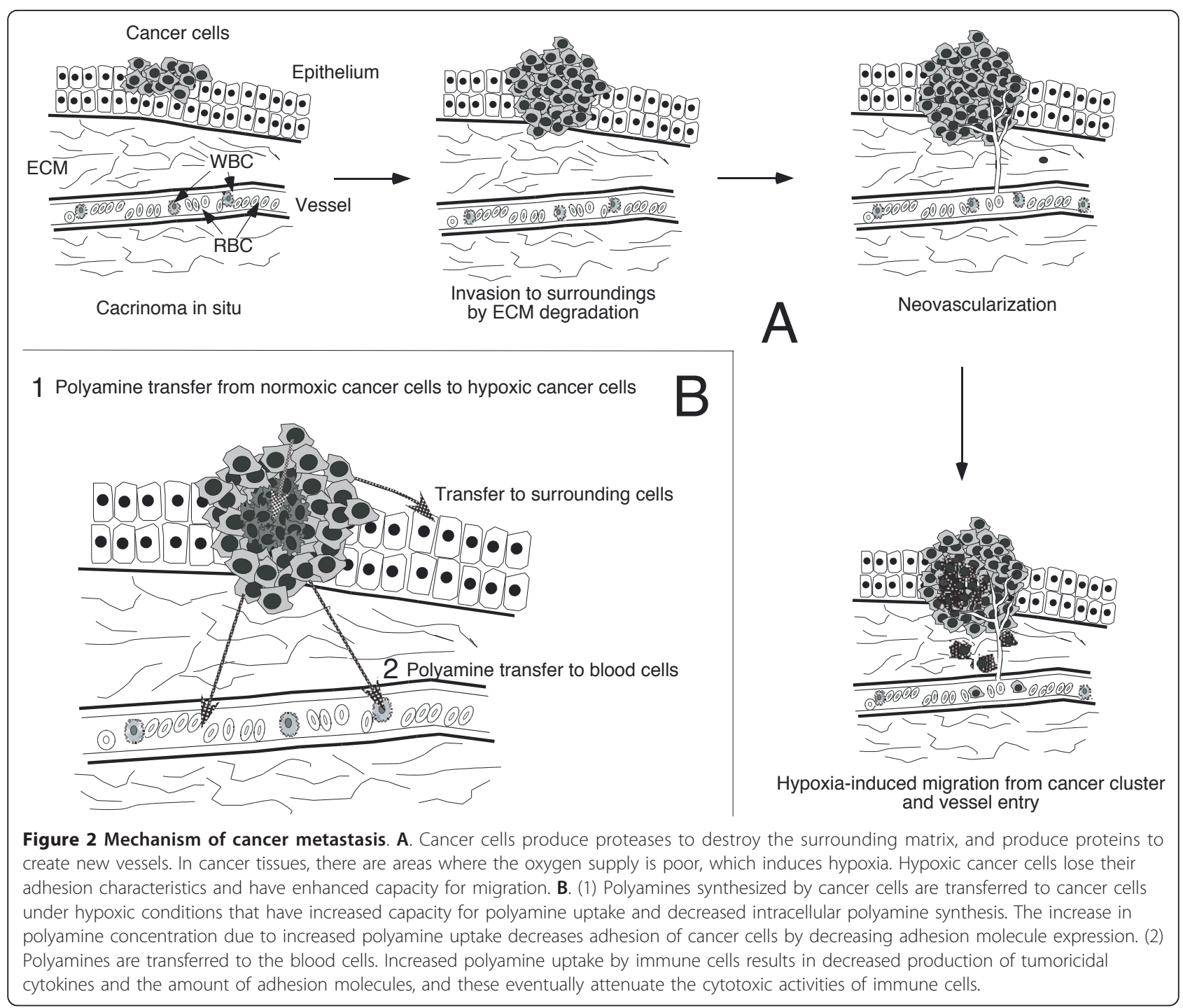

angiogenesis, anaerobic metabolism, cell survival, and invasion [61]. Among these, suppression of adhesion molecules induced by hypoxia-induced HIF-1 stabilization is a strong selective pressure that enhances outgrowth of cells with high-grade malignancy. CD44 and E-cadherin are adhesion molecules whose expression decreases in response to hypoxia $[62,63]$.

In cells exposed to chronic hypoxia, polyamine synthesis is decreased, while the ability to take up polyamines from the surroundings is increased $[64,65]$. Cells in a hypoxic environment have a resultant decrease in $d e$ novo polyamine synthesis and a concurrent increased capacity to take up polyamines from surrounding tissues, e.g. from cancer cells under normoxic conditions that are capable of producing abundant polyamines. We reported that cancer cells under hypoxia lose regulation of polyamine homeostasis and have increased polyamine uptake from surrounding tissues (Figure 2B, 1) [66]. The expression of the adhesion molecule CD44 is suppressed in response to hypoxia. Reduced CD44 expression is reported to promote cancer metastasis and invasion, allowing detachment of cancer cells from the primary tumor cluster and seems to contribute to the increased migration capacity of hypoxic HT-29 cells $[67,68]$. In conjunction with hypoxia, increases in extracellular spermine specifically augmented hypoxia-induced decreases in CD44 expression, and these decreases correlated well with increased migration of cancer cells (HT-29) in a dose-dependent manner [66]. In addition, several experiments indicated a possible role for polyamines in the invasive potential of cancer cells $[53,55,69]$.

\section{5-b. Role of polyamines in cancer cell transmigration to the circulation}

Cancer invasion is the process in which cancer cells migrate through surrounding tissues and enter into a 
blood vessel, which enables cancer cells to be transported throughout the body and establish secondary tumors. Blood vessel entry requires that cancer cells not only have increased motility but also secrete enzymes that degrade the surrounding cells' extracellular matrix (ECM), which is composed of the interstitial matrix and basement membrane, and provides structural support to cells. Cancer cells produce various proteinases, such as serine proteinase, matrix metalloproteinases (MMPs), cathepsins, and plasminogen activator that degrade the ECM [70-72]. In addition, cancer cells have the ability to create new blood vessels in the tumor, i.e. angiogenesis, so that cancer cells can obtain supplies of blood and oxygen [73].

Increased polyamine synthesis appears to be accompanied by cancer invasiveness as ODC overexpression enhances the invasive characteristics of cancer cells [74]. In contrast, inhibition of polyamine synthesis by the ODC inhibitor DFMO attenuates the invasive characteristics of cancer cells $[53,55,75]$, and supplementation with polyamine reverses the DFMO-induced decrease in invasive qualities [75]. The close correlation between increased polyamine synthesis and increased MMP synthesis has also been shown using DFMO, which caused decreases in cancer cell expression and concentrations of MMPs, such as matrilysin, meprin, and MMP-7 [76,77].

As mentioned above, increased polyamine synthesis is also accompanied by angiogenesis that is stimulated by cellular production of several factors, including vascular endothelial growth factor, which allow tumor tissues to grow and survive by obtaining sufficient blood supplies [78]. DFMO has been shown to exert its anti-tumor activity by inhibiting the proliferation of endothelial cells [79].

\section{5-c. Possible role of polyamines on cell rooting and colonization at secondary tumor sites}

Cancer cells that invade blood vessels and escape from immune system detection in circulation anchor to endothelial vasculature to establish new sites of growth. Upon vessel entry, cancer cells have access to abundant oxygen supplies that could enable cancer cells to restore their original activities such as increased gene expression that translates to enhanced enzymatic activities for polyamine synthesis, proteinase, and angiogenesis factors. Considering the results of our study, the expression of CD44 of normoxic cancer cells is higher than that of hypoxic cells [66], suggesting that the circulating cancer cells possibly recover their original adhesion characteristics. Once cancer cells anchor to the vessel wall of tissues and organs at secondary growth sites, they invade and rapidly grow because of their increased capacity to synthesize polyamines indispensable for cell growth and proteins that degrade the tissue matrix and create new vessels.

\section{5-d. Polyamines help cancer cells escape immune system detection}

Immune suppression, often observed in cancer patients, accelerates cancer spread. Various defects in cellular functions indicative of immune suppression have been reported, including attenuated adhesion properties of peripheral blood mononuclear cells (PBMCs) [80-82], impaired production of tumoricidal cytokines and chemokines [83-85], and decreased cytotoxic activity of killer cells, especially lymphokine activated killer (LAK) cells [86-89]. Several investigators have suggested that circulating factors that inhibit host immune activities are present in cancer patients [89-91]. The suppression of immune function in cancer patients can be restored following tumor eradication, further suggesting the presence of increased immunosuppressive substance(s) in cancer patients $[83,84,89,91]$.

The increases in blood polyamine concentrations in cancer patients reflect increased polyamine concentrations in blood cells, mainly in red and white blood cells (Figure 2B, 2). The in vitro effects of polyamines on immune functions were first reported over 30 years ago [92]. However, later analysis revealed that the reported immunosuppressive effects are induced not by the direct effect of polyamines but by substances produced by the interaction between polyamines and serum amine oxidase, present exclusively in ruminants, making these results difficult to extend to humans, which lack this enzyme. Nonetheless, animal experiments have shown that polyamine deprivation prevents the development of tumor-induced immunosuppression [93].

The adhesion characteristics of immune cells are important for eliciting anti-tumor cytotoxic activity, because adhesion is crucial for immune cell recognition of tumor cells [94]. Due to decreased adhesion, immune cells fail to recognize cancer cells or exert tumoricidal activities. Such decreases in immune cell adhesion are observed not only in cancer patients but also in patients having non-cancerous lesions [82]. These findings suggest the possibility that common factor(s), not specifically produced in cancer patients, can induce immunosuppressive conditions. Polyamines are one such factor, because blood polyamine levels, namely levels in blood cells including immune cells, are often increased in patients with various diseases [36,95-97].

Immune cells also take up polyamines form their surroundings [98,99], and the increase in blood polyamine concentrations often observed in cancer patients as well as in patients with other diseases reflects the increased polyamine levels in leukocytes $[36,100]$. We have shown that increased concentrations of spermine or spermidine 
in cultured human PBMCs suppress adhesion without sacrificing cell viability and activity.

The time- and dose-dependent decrease in adhesion produced by polyamines was accompanied by decreases in the expression of lymphocyte function-associated antigen-1 (LFA-1), which consists of an integrin alpha L (CD11a) and beta 2 (CD18) chain [41]. Polyamines in particular decrease the number of cells expressing bright CD11a. Such suppression was exclusively observed for LFA-1 with most other adhesion molecules tested unaffected by polyamines. The suppression of LFA-1 expression by polyamines was further confirmed in human healthy volunteers with polyamines suppressing LFA-1 expression on PBMCs, regardless of the volunteer's age [41]. In addition to LFA-1 suppression by polyamines, the number of CD56 bright cells was decreased by polyamines in vitro, although the effect was not confirmed in vivo. LFA-1 and CD56 contribute to the induction of tumoricidal cell activities, especially lymphokine activated killer (LAK) activity [101,102]. LAK cells, which have tumoricidal activities against established (existing) tumors, are induced by co-culture with IL-2 [103,104]. In animal experiments, polyamine deprivation reversed the tumor inoculation-induced suppression of IL-2 production without decreasing the number of $\mathrm{T}$ lymphocytes [93]. In addition, polyamines (spermine and spermidine) inhibit the production of tumoricidal cytokines, such as tumor necrosis factor (TNF), and chemokines in vitro, while they do not inhibit production of transforming growth factor beta, which has immunosuppressive properties [105-107]. Conversely, in animal experiments, polyamine deprivation has been shown to enhance chemokine production, reverse tumor inoculation-induced inhibition of killer cell activity, and prevent tumor-induced immune suppression [108,109].

TNF is able to induce apoptotic cell death and to attack and destroy cancer cells [110], while LFA-1 and CD56, especially bright CD11a and bright CD56 cells, are required for the induction of LAK cell cytotoxic activity $[111,112]$. Polyamines suppress LAK cytotoxicity without decreasing cell viability and activity in vitro, and the changes in blood spermine levels are negatively associated with changes in LAK cytotoxicity in cancer patients [42].

\section{Sources of polyamines other than cancer cells}

Food is an important source of polyamines. Polyamines in the intestinal lumen are absorbed quickly and distributed to all organs and tissues $[29,39,40]$. Moreover, continuous intake of polyamine-rich food gradually increases blood polyamine levels [30,31]. Therefore, the restricted intake of food polyamine and inhibition of polyamine synthesis by microbiota in the intestine with or without inhibitor-induced inhibition of polyamine synthesis is reported to have favorable effects on cancer therapy [33,113-115].

Trauma, such as surgery, is itself considered to increase the risk of cancer spread through various mechanisms [116-118]. Blood concentration and urinary excretion of polyamines are known to increase after surgery, although the origin of this increase is not well established $[97,119]$. Our previous study showed that increases in blood polyamine levels are inversely associated with anti-tumor LAK cytotoxicities in patients who have undergone surgery [42]. In addition to mechanisms previously postulated for post-traumatic cancer spread, post-operative increases in polyamines may be another factor that accelerates tumor growth.

\section{Conclusion}

As polyamines are essential for cell growth, one of the mechanisms by which polyamines accelerate tumor growth is through the increased availability of this indispensable growth factor. In addition, polyamines seem to accelerate tumor invasion and metastasis not only by suppressing immune system activity against established (already existing) tumors but also by enhancing the ability of invasive and metastatic capability of cancer cells. When considering the mechanism by which polyamines elicit their biological activities on immune and cancer cell functions, inhibition of polyamine uptake by cells seems to be an important target for polyamine-based cancer therapy particularly because inhibition of polyamine synthesis alone failed to produce a favorable effect on cancer treatments in several clinical trials. In addition to inhibiting polyamine synthesis and supply, inhibition of polyamine uptake via the polyamine transporter may have beneficial effects $[120,121]$.

\section{List of abbreviations}

APAO: $N^{1}$-acetylpolyamine oxidase; DFMO: D, L-a-difluoromethylornithine; ECM: extracellular matrix; HIF-1: hypoxia inducible factor-1; LAK: lymphokine activated killer; LFA-1: lymphocyte function-associated antigen-1; MGBG: methylglyoxal bis-(guanylhydrazone); MMPs: matrix metalloproteinases; ODC: ornithine decarboxylase; PBMCs: peripheral blood mononuclear cells; SAM: SAdenosylmethionine; SSAT: spermidine/spermine N1-acetyltransferase; TNF: tumor necrosis factor.

Authors' contributions

KS contributed solely to the writing and submission of this work.

Competing interests

The authors declare that they have no competing interests.

Received: 15 July 2011 Accepted: 11 October 2011

Published: 11 October 2011

\section{References}

1. Durie BG, Salmon SE, Russell DH: Polyamines as markers of response and disease activity in cancer chemotherapy. Cancer Res 1977, 37:214-221.

2. Loser C, Folsch UR, Paprotny C, Creutzfeldt W: Polyamines in colorectal cancer. Evaluation of polyamine concentrations in the colon tissue, 
serum, and urine of 50 patients with colorectal cancer. Cancer 1990, 65:958-966.

3. Chatel M, Darcel F, Quemener V, Hercouet H, Moulinoux JP: Red blood cell polyamines as biochemical markers of supratentorial malignant gliomas. Anticancer Res 1987, 7:33-38.

4. Kubota S, Okada M, Yoshimoto M, Murata N, Yamasaki Z, Wada T, Imahori K, Ohsawa N, Takaku F: Urinary polyamines as a tumor marker. Cancer Detect Prev 1985, 8:189-192.

5. Uehara N, Shirakawa S, Uchino H, Saeki Y: Elevated contents of spermidine and spermine in the erythrocytes of cancer patients. Cancer 1980, 45:108-111.

6. Cipolla B, Guille F, Moulinoux JP, Bansard JY, Roth S, Staerman F, Corbel L, Quemener V, Lobel B: Erythrocyte polyamines and prognosis in stage D2 prostatic carcinoma patients. J Urol 1994, 151:629-633.

7. Weiss TS, Bernhardt G, Buschauer A, Thasler WE, Dolgner D, Zirngibl H, Jauch KW: Polyamine levels of human colorectal adenocarcinomas are correlated with tumor stage and grade. Int I Colorectal Dis 2002, 17:381-387.

8. Linsalata M, Caruso MG, Leo S, Guerra V, D'Attoma B, Di Leo A: Prognostic value of tissue polyamine levels in human colorectal carcinoma. Anticancer Res 2002, 22:2465-2469.

9. Bergeron C, Bansard JY, Le Moine P, Bouet F, Goasguen JE, Moulinoux JP, Le Gall E, Catros-Quemener V: Erythrocyte spermine levels: a prognostic parameter in childhood common acute lymphoblastic leukemia. Leukemia 1997, 11:31-36.

10. Russell DH: Clinical relevance of polyamines. Crit Rev Clin Lab Sci 1983, 18:261-311.

11. Hochman J, Katz A, Bachrach U: Polyamines and protein kinase II. Effect of polyamines on cyclic AMP-dependent protein kinase from rat liver. Life Sci 1978, 22:1481-1484.

12. Tabib A, Bachrach U: Activation of the proto-oncogene c-myc and c-fos by c-ras: involvement of polyamines. Biochem Biophys Res Commun 1994 202:720-727.

13. Panagiotidis CA, Artandi S, Calame K, Silverstein SJ: Polyamines alter sequence-specific DNA-protein interactions. Nucleic Acids Res 1995, 23:1800-1809.

14. Childs AC, Mehta DJ, Gerner EW: Polyamine-dependent gene expression. Cell Mol Life Sci 2003, 60:1394-1406.

15. Seiler N: Polyamine oxidase, properties and functions. Prog Brain Res 1995, 106:333-344

16. Casero RA, Pegg AE: Polyamine catabolism and disease. Biochem J 2009, 421:323-338.

17. Pegg AE: Mammalian polyamine metabolism and function. IUBMB Life 2009, 61:880-894.

18. Gerner EW, Meyskens FL Jr: Polyamines and cancer: old molecules, new understanding. Nat Rev Cancer 2004, 4:781-792.

19. Erdman $\mathrm{SH}$, Ignatenko NA, Powell MB, Blohm-Mangone KA, Holubec $\mathrm{H}$, Guillen-Rodriguez JM, Gerner EW: APC-dependent changes in expression of genes influencing polyamine metabolism, and consequences for gastrointestinal carcinogenesis, in the Min mouse. Carcinogenesis 1999, 20:1709-1713.

20. Becciolini A, Porciani S, Lanini A, Balzi M, Cionini L, Bandettini L: Polyamine levels in healthy and tumor tissues of patients with colon adenocarcinoma. Dis Colon Rectum 1991, 34:167-173.

21. Canizares F, Salinas J, de las Heras M, Diaz J, Tovar I, Martinez P, Penafiel R: Prognostic value of ornithine decarboxylase and polyamines in human breast cancer: correlation with clinicopathologic parameters. Clin Cancer Res 1999, 5:2035-2041.

22. Radford DM, Nakai H, Eddy RL, Haley LL, Byers MG, Henry WM, Lawrence DD, Porter CW, Shows TB: Two chromosomal locations for human ornithine decarboxylase gene sequences and elevated expression in colorectal neoplasia. Cancer Res 1990, 50:6146-6153.

23. Kingsnorth $A N$, Lumsden $A B$, Wallace HM: Polyamines in colorectal cancer. Br J Surg 1984, 71:791-794.

24. LaMuraglia GM, Lacaine F, Malt RA: High ornithine decarboxylase activity and polyamine levels in human colorectal neoplasia. Ann Surg 1986, 204:89-93

25. Takenoshita S, Matsuzaki S, Nakano G, Kimura H, Hoshi H, Shoda H, Nakamura T: Selective elevation of the N1-acetylspermidine level in human colorectal adenocarcinomas. Cancer Res 1984, 44:845-847.
26. Moulinoux JP, Quemener V, Khan NA, Delcros JG, Havouis R: Spermidine uptake by erythrocytes from normal and Lewis lung carcinoma (3LL) grafted mice: I. In vitro study. Anticancer Res 1989, 9:1057-1062.

27. Uda K, Tsujikawa T, Fujiyama Y, Bamba T: Rapid absorption of luminal polyamines in a rat small intestine ex vivo model. $\int$ Gastroenterol Hepatol 2003, 18:554-559.

28. Bardocz S, Brown DS, Grant G, Pusztai A: Luminal and basolateral polyamine uptake by rat small intestine stimulated to grow by Phaseolus vulgaris lectin phytohaemagglutinin in vivo. Biochim Biophys Acta 1990, 1034:46-52.

29. Bardocz S, Grant G, Brown DS, Ralph A, Pusztai A: Polyamines in foodimplications for growth and health. J Nutr Biochem 1993, 4:66-71.

30. Soda K, Kano Y, Sakuragi M, Takao K, Lefor A, Konishi F: Long-term oral polyamine intake increases blood polyamine concentrations. J Nutr Sci Vitaminol (Tokyo) 2009, 55:361-366.

31. Soda K, Dobashi Y, Kano Y, Tsujinaka S, Konishi F: Polyamine-rich food decreases age-associated pathology and mortality in aged mice. Exp Gerontol 2009, 44:727-732.

32. Brodal BP, Eliassen KA, Ronning H, Osmundsen H: Effects of dietary polyamines and clofibrate on metabolism of polyamines in the rat. $J$ Nutr Biochem 1999, 10:700-708.

33. Sarhan $\mathrm{S}$, Knodgen $\mathrm{B}$, Seiler $\mathrm{N}$ : The gastrointestinal tract as polyamine source for tumor growth. Anticancer Res 1989, 9:215-223.

34. D'Agostino L, Pignata S, Daniele B, D'Adamo G, Ferraro C, Silvestro G, Tagliaferri P, Contegiacomo A, Gentile R, Tritto G, et al: Polyamine uptake by human colon carcinoma cell line CaCo-2. Digestion 1990, 46(Suppl 2):352-359.

35. Feige JJ, Chambaz EM: Polyamine uptake by bovine adrenocortical cells. Biochim Biophys Acta 1985, 846:93-100.

36. Cooper KD, Shukla JB, Rennert OM: Polyamine compartmentalization in various human disease states. Clin Chim Acta 1978, 82:1-7.

37. Upp JR Jr, Saydjari R, Townsend CM Jr, Singh P, Barranco SC, Thompson JC: Polyamine levels and gastrin receptors in colon cancers. Ann Surg 1988, 207:662-669.

38. Hixson LJ, Garewal HS, McGee DL, Sloan D, Fennerty MB, Sampliner RE, Gerner EW: Ornithine decarboxylase and polyamines in colorectal neoplasia and mucosa. Cancer Epidemiol Biomarkers Prev 1993, 2:369-374.

39. Osborne DL, Seidel ER: Gastrointestinal luminal polyamines: cellular accumulation and enterohepatic circulation. Am J Physiol 1990, 258 G576-584.

40. Kobayashi M, Xu YJ, Samejima K, Goda H, Niitsu M, Takahashi M, Hashimoto Y: Fate of orally administered $15 \mathrm{~N}$-labeled polyamines in rats bearing solid tumors. Biol Pharm Bull 2003, 26:285-288

41. Soda K, Kano Y, Nakamura T, Kasono K, Kawakami M, Konishi F: Spermine, a natural polyamine, suppresses LFA-1 expression on human lymphocyte. J Immunol 2005, 175:237-245.

42. Kano Y, Soda K, Nakamura T, Saitoh M, Kawakami M, Konishi F: Increased blood spermine levels decrease the cytotoxic activity of lymphokineactivated killer cells: a novel mechanism of cancer evasion. Cancer Immunol Immunother 2007, 56:771-781.

43. Klein S, Miret JJ, Algranati ID, de Lustig ES: Effect of alphadifluoromethylornithine in lung metastases before and after surgery of primary adenocarcinoma tumors in mice. Biol Cell 1985, 53:33-36.

44. Herr HW, Kleinert EL, Conti PS, Burchenal JH, Whitmore WF Jr: Effects of alpha-difluoromethylornithine and methylglyoxal bis(guanylhydrazone) on the growth of experimental renal adenocarcinoma in mice. Cancer Res 1984, 44:4382-4385.

45. Luk GD, Abeloff MD, Griffin CA, Baylin SB: Successful treatment with DLalpha-difluoromethylornithine in established human small cell variant lung carcinoma implants in athymic mice. Cancer Res 1983, 43:4239-4243.

46. Kingsnorth AN, McCann PP, Diekema KA, Ross JS, Malt RA: Effects of alphadifluoromethylornithine on the growth of experimental Wilms' tumor and renal adenocarcinoma. Cancer Res 1983, 43:4031-4034.

47. Prados MD, Wara WM, Sneed PK, McDermott M, Chang SM, Rabbitt J, Page M, Malec M, Davis RL, Gutin PH, et al: Phase III trial of accelerated hyperfractionation with or without difluromethylornithine (DFMO) versus standard fractionated radiotherapy with or without DFMO for newly diagnosed patients with glioblastoma multiforme. Int I Radiat Oncol Biol Phys 2001, 49:71-77.

48. Messing E, Kim KM, Sharkey F, Schultz M, Parnes H, Kim D, Saltzstein D, Wilding G: Randomized prospective phase III trial of 
difluoromethylornithine vs placebo in preventing recurrence of completely resected low risk superficial bladder cancer. J Urol 2006, 176:500-504.

49. Meyskens FL Jr, McLaren CE, Pelot D, Fujikawa-Brooks S, Carpenter PM, Hawk E, Kelloff G, Lawson MJ, Kidao J, McCracken J, et al: Difluoromethylornithine plus sulindac for the prevention of sporadic colorectal adenomas: a randomized placebo-controlled, double-blind trial. Cancer Prev Res (Phila) 2008, 1:32-38.

50. Quemener V, Moulinoux JP, Havouis R, Seiler N: Polyamine deprivation enhances antitumoral efficacy of chemotherapy. Anticancer Res 1992, 12:1447-1453.

51. Thompson PA, Wertheim BC, Zell JA, Chen WP, McLaren CE, LaFleur BJ, Meyskens FL, Gerner EW: Levels of rectal mucosal polyamines and prostaglandin E2 predict ability of DFMO and sulindac to prevent colorectal adenoma. Gastroenterology 2010, 139:797-805, 805 e791.

52. Levin VA, Hess KR, Choucair A, Flynn PJ, Jaeckle KA, Kyritsis AP, Yung WK, Prados MD, Bruner JM, Ictech $S$, et al: Phase III randomized study of postradiotherapy chemotherapy with combination alphadifluoromethylornithine-PCV versus PCV for anaplastic gliomas. Clin Cancer Res 2003, 9:981-990.

53. Jun JY, Griffith JW, Bruggeman R, Washington S, Demers LM, Verderame MF, Manni A: Effects of polyamine depletion by alphadifluoromethylornithine on in vitro and in vivo biological properties of 4T1 murine mammary cancer cells. Breast Cancer Res Treat 2008, 107:33-40.

54. Kubota S, Ohsawa N, Takaku F: Effects of DL-alphadifluoromethylornithine on the growth and metastasis of B16 melanoma in vivo. Int J Cancer 1987, 39:244-247.

55. Manni A, Washington S, Hu X, Griffith JW, Bruggeman R, Demers LM, Mauger D, Verderame MF: Effects of polyamine synthesis inhibitors on primary tumor features and metastatic capacity of human breast cancer cells. Clin Exp Metastasis 2005, 22:255-263.

56. MacDonald NJ, Steeg PS: Molecular basis of tumour metastasis. Cancer Surv 1993, 16:175-199.

57. Liotta $L A$, Rao $C N$, Barsky $S H$ : Tumor invasion and the extracellular matrix. Lab Invest 1983, 49:636-649.

58. Klymkowsky MW, Savagner P: Epithelial-mesenchymal transition: a cancer researcher's conceptual friend and foe. Am J Pathol 2009, 174:1588-1593.

59. Pouyssegur J, Dayan F, Mazure NM: Hypoxia signalling in cancer and approaches to enforce tumour regression. Nature 2006, 441:437-443,

60. Hockel M, Vaupel P: Tumor hypoxia: definitions and current clinical, biologic, and molecular aspects. J Natl Cancer Inst 2001, 93:266-276.

61. Harris AL: Hypoxia-a key regulatory factor in tumour growth. Nat Rev Cancer 2002, 2:38-47.

62. Beavon IR: Regulation of E-cadherin: does hypoxia initiate the metastatic cascade? Mol Pathol 1999, 52:179-188.

63. Hasan NM, Adams GE, Joiner MC, Marshall JF, Hart IR: Hypoxia facilitates tumour cell detachment by reducing expression of surface adhesion molecules and adhesion to extracellular matrices without loss of cell viability. Br J Cancer 1998, 77:1799-1805.

64. Tantini B, Fiumana E, Cetrullo S, Pignatti C, Bonavita F, Shantz LM, Giordano E, Muscari C, Flamigni F, Guarnieri C, et al: Involvement of polyamines in apoptosis of cardiac myoblasts in a model of simulated ischemia. J Mol Cell Cardiol 2006, 40:775-782.

65. Aziz SM, Olson JW, Gillespie MN: Multiple polyamine transport pathways in cultured pulmonary artery smooth muscle cells: regulation by hypoxia. Am J Respir Cell Mol Biol 1994, 10:160-166.

66. Tsujinaka S, Soda K, Kano Y, Konishi F: Spermine accelerates hypoxiainitiated cancer cell migration. Int J Oncol 2011, 38:305-312.

67. De Marzo AM, Bradshaw C, Sauvageot J, Epstein Jl, Miller GJ: CD44 and CD44v6 downregulation in clinical prostatic carcinoma: relation to Gleason grade and cytoarchitecture. Prostate 1998, 34:162-168.

68. Kallakury BV, Yang F, Figge J, Smith KE, Kausik SJ, Tacy NJ, Fisher HA Kaufman R, Figge H, Ross JS: Decreased levels of CD44 protein and mRNA in prostate carcinoma. Correlation with tumor grade and ploidy. Cancer 1996, 78:1461-1469.

69. Sunkara PS, Rosenberger AL: Antimetastatic activity of DL-alphadifluoromethylornithine, an inhibitor of polyamine biosynthesis, in mice. Cancer Res 1987, 47:933-935.

70. Basset P, Okada A, Chenard MP, Kannan R, Stoll I, Anglard P, Bellocq JP, Rio MC: Matrix metalloproteinases as stromal effectors of human carcinoma progression: therapeutic implications. Matrix Biol 1997, 15:535-541.

71. Nelson AR, Fingleton B, Rothenberg ML, Matrisian LM: Matrix metalloproteinases: biologic activity and clinical implications. J Clin Oncol 2000, 18:1135-1149.

72. Kessenbrock K, Plaks V, Werb Z: Matrix metalloproteinases: regulators of the tumor microenvironment. Cell 2010, 141:52-67.

73. Dvorak HF, Weaver VM, TIsty TD, Bergers G: Tumor microenvironment and progression. J Surg Oncol 2011, 103:468-474.

74. Kubota S, Kiyosawa H, Nomura Y, Yamada T, Seyama Y: Ornithine decarboxylase overexpression in mouse 10T1/2 fibroblasts: cellular transformation and invasion. J Natl Cancer Inst 1997, 89:567-571.

75. Ashida $Y$, Kido J, Kinoshita F, Nishino M, Shinkai K, Akedo H, Inoue H: Putrescine-dependent invasive capacity of rat ascites hepatoma cells. Cancer Res 1992, 52:5313-5316.

76. Wallon UM, Shassetz LR, Cress AE, Bowden GT, Gerner EW: Polyaminedependent expression of the matrix metalloproteinase matrilysin in a human colon cancer-derived cell line. Mol Carcinog 1994, 11:138-144

77. Matters GL, Manni A, Bond JS: Inhibitors of polyamine biosynthesis decrease the expression of the metalloproteases meprin alpha and MMP-7 in hormone-independent human breast cancer cells. Clin Exp Metastasis 2005, 22:331-339.

78. Auvinen M, Laine A, Paasinen-Sohns A, Kangas A, Kangas L, Saksela O, Andersson LC, Holtta E: Human ornithine decarboxylase-overproducing $\mathrm{NIH} 3 \mathrm{~T} 3$ cells induce rapidly growing, highly vascularized tumors in nude mice. Cancer Res 1997, 57:3016-3025.

79. Takigawa M, Enomoto M, Nishida Y, Pan HO, Kinoshita A, Suzuki F: Tumor angiogenesis and polyamines: alpha-difluoromethylornithine, an irreversible inhibitor of ornithine decarboxylase, inhibits B16 melanomainduced angiogenesis in ovo and the proliferation of vascular endothelial cells in vitro. Cancer Res 1990, 50:4131-4138.

80. Hersh EM, Gschwind C, Morris DL, Murphy S: Deficient strongly adherent monocytes in the peripheral blood of cancer patients. Cancer Immunol Immunother 1982, 14:105-109.

81. Grosser N, Marti JH, Proctor JW, Thomson DM: Tube leukocyte adherence inhibition assay for the detection of anti-tumor immunity. I. Monocyte is the reactive cell. Int I Cancer 1976, 18:39-47.

82. MacFarlane JK, Thomson DM, Phelan K, Shenouda G, Scanzano R: Predictive value of tube leukocyte adherence inhibition (LAl) assay for breast, colorectal, stomach and pancreatic cancer. Cancer 1982, 49:1185-1193.

83. Heriot AG, Marriott JB, Cookson S, Kumar D, Dalgleish AG: Reduction in cytokine production in colorectal cancer patients: association with stage and reversal by resection. Br J Cancer 2000, 82:1009-1012.

84. Rampone B, Rampone A, Tirabasso S, Panariello S, Rampone N: Immunological variations in women suffering from ovarian cancer. Influence of radical surgical treatment. Minerva Ginecol 2001, 53:116-119.

85. Monson JR, Ramsden C, Guillou PJ: Decreased interleukin-2 production in patients with gastrointestinal cancer. Br J Surg 1986, 73:483-486.

86. Wood NL, Kitces EN, Blaylock WK: Depressed lymphokine activated killer cell activity in mycosis fungoides. A possible marker for aggressive disease. Arch Dermatol 1990, 126:907-913.

87. Hermann GG, Petersen KR, Steven K, Zeuthen J: Reduced LAK cytotoxicity of peripheral blood mononuclear cells in patients with bladder cancer: decreased LAK cytotoxicity caused by a low incidence of CD56+ and CD57+ mononuclear blood cells. J Clin Immunol 1990, 10:311-320.

88. Funk J, Schmitz G, Failing K, Burkhardt E: Natural killer (NK) and lymphokine-activated killer (LAK) cell functions from healthy dogs and 29 dogs with a variety of spontaneous neoplasms. Cancer Immunol Immunother 2005, 54:87-92.

89. Balch $C M$, Itoh $K$, Tilden $A B$ : Cellular immune defects in patients with melanoma involving interleukin-2-activated lymphocyte cytotoxicity and a serum suppressor factor. Surgery 1985, 98:151-157.

90. Hersey P, Bindon C, Czerniecki M, Spurling A, Wass J, McCarthy WH: Inhibition of interleukin 2 production by factors released from tumor cells. J Immunol 1983, 131:2837-2842.

91. Taylor DD, Bender DP, Gercel-Taylor C, Stanson J, Whiteside TL: Modulation of TCR/CD3-zeta chain expression by a circulating factor derived from ovarian cancer patients. Br J Cancer 2001, 84:1624-1629.

92. Byrd WJ, Jacobs DM, Amoss MS: Synthetic polyamines added to cultures containing bovine sera reversibly inhibit in vitro parameters of immunity. Nature 1977, 267:621-623. 
93. Chamaillard L, Catros-Quemener V, Delcros JG, Bansard JY, Havouis R, Desury D, Commeurec A, Genetet N, Moulinoux JP: Polyamine deprivation prevents the development of tumour-induced immune suppression. $\mathrm{Br} J$ Cancer 1997, 76:365-370.

94. Lotzova E, Savary CA, Totpal K, Schachner J, Lichtiger B, McCredie KB, Freireich EJ: Highly oncolytic adherent lymphocytes: therapeutic relevance for leukemia. Leuk Res 1991, 15:245-254.

95. Loser C, Folsch UR, Paprotny C, Creutzfeldt W: Polyamine concentrations in pancreatic tissue, serum, and urine of patients with pancreatic cancer. Pancreas 1990, 5:119-127.

96. Nishiguchi S, Tamori A, Koh N, Fujimoto S, Takeda T, Shiomi S, Oka H, Yano Y, Otani S, Kuroki T: Erythrocyte-binding polyamine as a tumor growth marker for human hepatocellular carcinoma. Hepatogastroenterology 2002, 49:504-507.

97. Nishioka K, Romsdahl MM, McMurtrey MJ: Serum polyamine alterations in surgical patients with colorectal carcinoma. J Surg Oncol 1977, 9:555-562.

98. Colombatto S, Fasulo L, Fulgosi B, Grillo MA: Transport and metabolism of polyamines in human lymphocytes. Int J Biochem 1990, 22:489-492.

99. Bardocz S, Grant G, Brown DS, Ewen SW, Nevison I, Pusztai A: Polyamine metabolism and uptake during Phaseolus vulgaris lectin, PHA-induced growth of rat small intestine. Digestion 1990, 46(Suppl 2):360-366.

100. Cohen LF, Lundgren DW, Farrell PM: Distribution of spermidine and spermine in blood from cystic fibrosis patients and control subjects. Blood 1976, 48:469-475.

101. Ellis TM, Fisher Rl: Functional heterogeneity of Leu 19"bright"+ and Leu 19"dim"+ lymphokine-activated killer cells. J Immunol 1989, 142:2949-2954.

102. Weil-Hillman G, Fisch P, Prieve AF, Sosman JA, Hank JA, Sondel PM: Lymphokine-activated killer activity induced by in vivo interleukin 2 therapy: predominant role for lymphocytes with increased expression of CD2 and leu19 antigens but negative expression of CD16 antigens. Cancer Res 1989, 49:3680-3688.

103. Mule JJ, Shu S, Schwarz SL, Rosenberg SA: Adoptive immunotherapy of established pulmonary metastases with LAK cells and recombinant interleukin-2. Science 1984, 225:1487-1489.

104. Rosenberg SA, Mule JJ, Spiess PJ, Reichert CM, Schwarz SL: Regression of established pulmonary metastases and subcutaneous tumor mediated by the systemic administration of high-dose recombinant interleukin 2 . $J$ Exp Med 1985, 161:1169-1188.

105. Soda K, Kano Y, Nakamura T, Kawakami M, Konishi F: Spermine and spermidine induce some of the immune suppression observed in cancer patients. Annals of Cancer Research and Therapy 2003, 11:243-253.

106. Zhang M, Caragine T, Wang H, Cohen PS, Botchkina G, Soda K, Bianchi M, Ulrich P, Cerami A, Sherry B, Tracey KJ: Spermine inhibits proinflammatory cytokine synthesis in human mononuclear cells: a counterregulatory mechanism that restrains the immune response. J Exp Med 1997, 185:1759-1768.

107. Hasko G, Kuhel DG, Marton A, Nemeth ZH, Deitch EA, Szabo C: Spermine differentially regulates the production of interleukin-12 p40 and interleukin-10 and suppresses the release of the T helper 1 cytokine interferon-gamma. Shock 2000, 14:144-149.

108. Bowlin TL, McKown BJ, Sunkara PS: The effect of alphadifluoromethylornithine, an inhibitor of polyamine biosynthesis, on mitogen-induced interleukin 2 production. Immunopharmacology 1987, 13:143-147.

109. Chamaillard L, Quemener V, Havouis R, Moulinoux JP: Polyamine deprivation stimulates natural killer cell activity in cancerous mice. Anticancer Res 1993, 13:1027-1033.

110. Carswell EA, Old LJ, Kassel RL, Green S, Fiore N, Williamson B: An endotoxin-induced serum factor that causes necrosis of tumors. ProC Natl Acad Sci USA 1975, 72:3666-3670

111. Wacholtz MC, Patel SS, Lipsky PE: Leukocyte function-associated antigen 1 is an activation molecule for human T cells. J Exp Med 1989, 170:431-448.

112. Ferrini S, Sforzini S, Cambiaggi A, Poggi A, Meazza R, Canevari S, Colnaghi MI, Moretta L: The LFA-1/ICAM cell adhesion pathway is involved in tumor-cell lysis mediated by bispecific monoclonal-antibodytargeted T lymphocytes. Int J Cancer 1994, 56:846-852.

113. Sarhan S, Weibel M, Seiler N: Effect of polyamine deprivation on the survival of intracranial glioblastoma bearing rats. Anticancer Res 1991, 11:987-992.
114. Seiler N, Sarhan S, Grauffel C, Jones R, Knodgen B, Moulinoux JP: Endogenous and exogenous polyamines in support of tumor growth. Cancer Res 1990, 50:5077-5083.

115. Cipolla BG, Havouis R, Moulinoux JP: Polyamine reduced diet (PRD) nutrition therapy in hormone refractory prostate cancer patients. Biomed Pharmacother 2010, 64:363-368.

116. Page GG, Ben-Eliyahu S, Liebeskind JC: The role of LGL/NK cells in surgeryinduced promotion of metastasis and its attenuation by morphine. Brain Behav Immun 1994, 8:241-250.

117. Pollock RE, Babcock GF, Romsdahl MM, Nishioka K: Surgical stressmediated suppression of murine natural killer cell cytotoxicity. Cancer Res 1984, 44:3888-3891.

118. Hattori T, Hamai $Y$, Harada T, Ikeda H, Ikeda T: Enhancing effect of thoracotomy and/or laparotomy on the development of the lung metastases in rats after intravenous inoculation of tumor cells. Jpn J Surg 1977, 7:263-268

119. Tsukamoto T, Kinoshita H, Hirohashi K, Kubo S, Otani S: Human erythrocyte polyamine levels after partial hepatectomy. Hepatogastroenterology 1997, 44:744-750.

120. Aziz SM, Gillespie MN, Crooks PA, Tofiq SF, Tsuboi CP, Olson JW Gosland MP: The potential of a novel polyamine transport inhibitor in cancer chemotherapy. J Pharmacol Exp Ther 1996, 278:185-192.

121. Chen Y, Weeks RS, Burns MR, Boorman DW, Klein-Szanto A, O'Brien TG: Combination therapy with 2-difluoromethylornithine and a polyamine transport inhibitor against murine squamous cell carcinoma. Int J Cancer 2006, 118:2344-2349.

doi:10.1186/1756-9966-30-95

Cite this article as: Soda: The mechanisms by which polyamines accelerate tumor spread. Journal of Experimental \& Clinical Cancer Research $201130: 95$

\section{Submit your next manuscript to BioMed Central and take full advantage of:}

- Convenient online submission

- Thorough peer review

- No space constraints or color figure charges

- Immediate publication on acceptance

- Inclusion in PubMed, CAS, Scopus and Google Scholar

- Research which is freely available for redistribution

Submit your manuscript at www.biomedcentral.com/submit
C) Biomed Central 